\title{
HOW READY ARE PEOPLE FOR CASHLESS SOCIETY?
}

\author{
Irwan Trinugroho ${ }^{1}$, Hunik Sri Runing Sawitri ${ }^{1}$, Muh Juan Suam Toro ${ }^{1}$, \\ Siti Khoiriyah ${ }^{1}$, Arief Budi Santoso ${ }^{2}$ \\ ${ }^{1}$ Departemen Manajemen Fakultas Ekonomi dan Bisnis Universitas Sebelas Maret \\ Jl. Ir. Sutami No.36A Surakarta, 57126, Indonesia \\ ${ }^{2}$ Kantor Perwakilan Bank Indonesia Yogyakarta \\ Jl. Panembahan Senopati No.4-6 Yogyakarta, 55121, Indonesia
}

\begin{tabular}{|c|c|}
\hline \multirow[b]{2}{*}{$\begin{array}{l}\text { Keywords: } \\
\text { Cashless Society, } \\
\text { Demographic } \\
\text { Characteristics, } \\
\text { Digital Financial } \\
\text { Services, Financial } \\
\text { Inclusion, Infrastruc- } \\
\text { ture, } \\
\text { JEL Classification: } \\
\text { G20, G23, O33 }\end{array}$} & Abstract \\
\hline & $\begin{array}{l}\text { Financial technology could be an effective tool to achieve financial inclusion. However, it needed } \\
\text { a certain level of readiness of society. In this paper, we investigated the determinants of readiness } \\
\text { in the implementation of digital financial services which led to cashless society. We did a survey } \\
\text { on } 993 \text { adults in a province in Indonesia using proportional sampling technique. Estimated using } \\
\text { ordinary least square, our empirical results showed that readiness perception had high correlation } \\
\text { with the quality of supporting infrastructure. By taking into account some demographic factors, } \\
\text { we found that more educated and younger people had high spirit to adopt this system. Evidence } \\
\text { showed that men were more enthusiastic in using such technological-based system. However, we } \\
\text { did not find an evidence on the difference of readiness perception between those living in rural and } \\
\text { those living urban areas. }\end{array}$ \\
\hline & Abstrak \\
\hline $\begin{array}{l}\text { Kata kunci: } \\
\text { Masyarakat Non- } \\
\text { tunai, Karakteristik } \\
\text { Demografi, } \\
\text { Layanan } \\
\text { Keuangan Digital, } \\
\text { Inklusi Keuangan, } \\
\text { Infrastruktur }\end{array}$ & $\begin{array}{l}\text { Teknologi keuangan dapat menjadi suatu alat yang efektif untuk mencapai inklusi } \\
\text { keuangan. Namun, itu memerlukan tingkat kesiapan masyarakat yang cukup. Dalam } \\
\text { paper ini, kami meneliti determinan dari kesiapan implementasi layanan keuangan digi- } \\
\text { tal yang mendorong pada masyarakat non-tunai. Kami melakukan survei pada } 993 \text { or- } \\
\text { ang dewasa in suatu provinsi di Indonesia dengan menggunakan metode pengambilan } \\
\text { sampel proporsional. Diestimasi menggunakan ordinary least square, hasil empiris kami } \\
\text { menunjukkan bahwa persepsi kesiapan berkorelasi tinggi dengan kualitas dari } \\
\text { infrastruktur pendukung. Dengan memasukkan beberapa faktor demografi, kami } \\
\text { menemukan bahwa orang yang lebih teredukasi dan lebih muda bersemangat untuk } \\
\text { mengadopsi sistem ini. Sedikit bukti ditemukan bahwa laki-laki lebih antusias untuk } \\
\text { menggunakan sistem berbasis teknologi tersebut. Namun demikian, kami tidak } \\
\text { menemukan bukti mengenai perbedaaan persepsi kesiapan antara mereka yang tinggal } \\
\text { di daerah pedesaan dan perkotaan. }\end{array}$ \\
\hline
\end{tabular}


Financial inclusion has been widely considered to be an essential way to achieve well-distributed economic growth (e.g. Beck et al., 2009; Trinugroho et al., 2015). Many scholars, regulators and business practitioners have paid more attention on this matter and it has been a global issue (Gupte et al., 2012; Gwalani \& Parkhi, 2014). Financial inclusion could be defined as the access to formal financial institutions at an affordable cost for all participants of an economy, putting more weight for the poor (Diniz et al., 2012).

There have been some models in the evolution of financial innovation to date such as peer to peer lending (e.g. Milne \& Parboteeah, 2016), crowd funding (e.g. Parker, 2014; Hernando, 2016), electronic money and mobile payment (e.g. Dahlberg, 2015), as well as other recent development in the digital financial services. In this study, we focus on the implementation digital financial services in Indonesia which is a part of the financial inclusion program. As explained by Diniz et al. (2012), the successful of financial inclusion program is widely found in emerging countries in which the use of information and communication technology in the financial services is broader. Similarly, Gwalani \& Parkhi (2014) also mention that the adoption of technology could be considered to enhance the level of financial inclusion. Similarly, Pradhan et al. (2015) explain that information and communications technology (ICT) infrastructure plays significant role in the financial development.

The Indonesian government has committed to accelerate the level of financial inclusion. A substantial proportion of Indonesian people are still financially illiterate which in turn they do not have access to formal financial system. According to the survey of Bank Indonesia in 2012, only $35.31 \%$ of people have benefitted from banking services. Moreover, in 2011, Bank Indonesia documents that only $48 \%$ of households have saving account in banks, non-bank financial institutions, and non- financial institutions such as cooperation. Santoso et al. (2015), in their survey, point out that the correlation between financial literacy and financial inclusion in a province in Indonesia is only 0.271 which means that a large number of people are not financially included even though they have basic knowledge of finance. At the aggregate level, Astuti \& Trinugroho (2016) document that financial literacy is positively associated with engagement of poor people to the formal financial institutions. Moreover, Karsidi et al. (2015) reveal that due to poor people are not confident to approach formal financial institutions; they borrow money from informal (illegal) lenders, in addition to economic insecurity factor.

To widen the access to financial services, especially for unbanked and underbanked society, Bank Indonesia has made some innovation through the introduction of digital financial services (DFS) which is formerly known as branchless banking program. This program has been launched in 2013 and the pilot project has been conducted by five banks in collaboration with some telecommunication companies in five provinces. Furthermore, the Bank Indonesia issued a regulation No. 16/8/ PBI/ 2014 to replace the regulation No. 11/12/PBI/ 2009 regarding electronic money and strengthened by the circulation letter of Bank Indonesia No. 16/ 12/DPAU on the implementation of digital financial services in the framework of financial inclusion through the individual agents.

The present paper investigates the determinants of perceived readiness of people for the implementation of digital financial services which in turn will lead to a cashless society. Our focus here is more on the use of electronic money for payment and other activities.

\section{METHOD}

Our sample consists of 993 adults living in the Special province of Yogyakarta in Indonesia 


\section{How Ready are People for Cashless Society? \\ Irwan Trinugroho, Hunik Sri Runing Sawitri, Muh Juan Suam Toro, Siti Khoiriyah, \& Arief Budi Santoso}

which has five districts/ municipals (Bantul, Gunungkidul, Kulonprogo, Sleman and Yogyakarta City). We did in-depth interview to ensure that our respondents fully understand on what we ask. To meet our research objective, our criteria to be selected as respondent are more than 17 years old, having mobile phone and having job. Our sample is proportionally distributed across district.

Our dependent variable is the perceived readiness to the implementation of digital financial services (READINESS). We include some determinant factors to explain our dependent variable including infrastructure, demographic characteristics, socio-economic condition and sub-district characteristics. Infrastructure is measure by an index (INFRA) which is comprised from aggregate perception of respondents regarding the quality of supporting infrastructure including banking, telecommunication, electricity, transportation, access to business center and others. We take into account some demographic characteristics to explain the difference in readiness to adopt such technological-based financial services. First, we include a dummy variable to reflect gender difference (GENDER), taking a value of 1 for male respondents and o for female respondents. Following our previous work (Santoso et al., 2016), we measure education level (EDU) using an interval scale. The last demographic factor is the age of respondents (AGE) as one might argue that the use of a new technology is easier for young people. Socio-economic condition which reflects living quality (Trinugroho et al., 2015) is represented by the income level (INCOME) which also employs an interval scale. Sub-district characteristics are proxied by the degree of ruralness (RURAL) according to the study of Santoso et al. (2016). It is supposed that people in the rural area may perceive themselves less friendly with technologicalbased financial services. For robustness check purpose, we introduce the number of banks in the sub-district and the ratio of population per bank to capture the characteristic difference between sub-districts. A vector of dummy variables (DISTRICTS) to control for district idiosyncratic factors is also included in the model.

We estimate our empirical model using ordinary least square. Our empirical model to be estimated is as follows:

$$
\begin{aligned}
\text { READINESS }_{i}= & \alpha_{0}+\alpha_{1} \text { INFRA }_{i}+\alpha_{2} \text { GENDER }_{i}+ \\
& \alpha_{3} \text { EDU }_{i}+\alpha_{4} \text { AGE }_{i}+\alpha_{5} \text { INCOME }_{i}+ \\
& \alpha_{6} \text { RURAL }_{i}+\text { DISTRICTS }_{i}+\varepsilon_{i, t}
\end{aligned}
$$

\section{RESULTS}

Table 1 shows the statistics of the variables included in the regression model. The average perceived readiness is 14.606 and the mean of index on perception of infrastructure quality is 43.299. $60.2 \%$ of our respondent is men, while the average education of respondents is between senior high school and diploma at the higher education. The average income of respondents is 2.603 which means in the interval of $2-3$ million Rupiah per month (at the time being, it is equal to 138 207 USD). The average degree of ruralness is 1.464 which means the numbers of sub-districts in rural and urban areas are almost the same.

Table 2 presents the correlation matrix of variables. As expected, the infrastructure index is positively and significantly correlated with perceived readiness in the implementation of digital financial services. Similarly, the correlation between education level and readiness as well as between income and readiness are positive and significant. Age is found to be negatively and significantly correlated with readiness. Likewise, negative correlation between ruralness and readiness is documented.

Table 3 presents the regression results. It is a cross-sectional study as data is collected for a certain period. We estimate our empirical model 
using ordinary least square (OLS). As explained earlier, our dependent variable is an index to represent the readiness in the implementation of digital financial services. We include some determinant factors to explain our dependent variable including infrastructure, demographic characteristics, socio-economic condition and sub-district characteristics. To deal with the idiosyncratic of districts, we include dummy variables representing each district.

Our results show that infrastructure is positively and significantly associated with perceived readiness in the implementation of cashless system. Turn to the demographic characteristics, we find that the higher the education it would like to higher perception on the readiness to engage in digital financial services. The empirical results also document that age is negatively correlated with the readiness which means that younger people are more ready to use the digital financial services. It may come from the fact that young people are more familiar and have large exposure to technology and information system. Little evidence is found that male respondents have higher level of readiness than female respondents. Men are widely known to be more confident and risk taking than women.

As expected, those with higher income should be more ready to adopt digital financial services. It could be argued that with a higher income, people have large engagement with banking services. However, we do not find evidence that the degree of ruralness as a proxy of sub-district characteristic.

\section{Robustness Checks}

Some robustness checks are made to ensure the consistency of our results. First, we change the proxy of ruralness to the number of banks in the sub-district (column 2 of Table 3). Again, we do find that number of banks do not have significant effect on perceived readiness. With regard to other variables, the results are consistent. Second, we shift the measure of sub-district characteristic to the ratio of population of sub-district per bank. It also indicates the bank coverage for each sub-district. It may be argued that in the sub-districts with larger population, the need of financial services is higher as well. However, the effect of other variables remains unchanged.

Table 1. Descriptive Statistics

\begin{tabular}{lrrrrrrr}
\hline & READINESS & INFRA & GENDER & EDU & AGE & INCOME & \multicolumn{1}{c}{ RURAL } \\
\hline Mean & 14.606 & 43.299 & 0.602 & 4.355 & 36.841 & 2.603 & 1.464 \\
Median & 15.000 & 44.000 & 1.000 & 4.000 & 35.000 & 2.000 & 1.400 \\
Maximum & 20.000 & 60.000 & 1.000 & 7.000 & 85.000 & 6.000 & 2.000 \\
Minimum & 9.000 & 24.000 & 0.000 & 1.000 & 16.000 & 1.000 & 1.000 \\
Std. Dev. & 1.701 & 5.076 & 0.490 & 1.129 & 11.704 & 1.441 & 0.425 \\
Skewness & -0.158 & -0.431 & -0.418 & 0.166 & 0.550 & 0.980 & 0.115 \\
\hline Observations & 993 & 993 & 993 & 993 & 993 & 993 & 993 \\
\hline
\end{tabular}

Table 1 exhibits the descriptive statistics of variables. READINESS is an index to measure the perceived readiness in the implementation of digital financial services. INFRA is an index to measure the perceived quality of supporting infrastructure. GENDER is a dummy variable, taking a value of 1 for male and 0 for female. EDU is the level of education. AGE is the age of respondent. INCOME is the level of income. RURAL is the level of ruralness. 
Table 2. Correlation Matrix of Variables

\begin{tabular}{|c|c|c|c|c|c|c|c|c|c|c|c|c|}
\hline & $\begin{array}{l}\text { READI } \\
\text { NESS }\end{array}$ & INFRA & $\begin{array}{l}\text { GEN } \\
\text { DER }\end{array}$ & EDU & AGE & $\begin{array}{c}\text { INCO } \\
\text { ME }\end{array}$ & $\begin{array}{l}\text { RURAL } \\
\text { NESS }\end{array}$ & YOGYA & $\begin{array}{l}\text { SLE } \\
\text { MAN }\end{array}$ & BANTUL & KULONPROGO & GUNUNGKIDUL \\
\hline READINESS & 1.000 & & & & & & & & & & & \\
\hline INFRA & 0.232 & 1.000 & & & & & & & & & & \\
\hline GENDER & 0.032 & -0.003 & 1.000 & & & & & & & & & \\
\hline EDU & 0.292 & 0.139 & 0.003 & 1.000 & & & & & & & & \\
\hline AGE & -0.192 & -0.108 & 0.166 & -0.071 & 1.000 & & & & & & & \\
\hline INCOME & 0.181 & 0.154 & 0.129 & 0.391 & 0.234 & 1.000 & & & & & & \\
\hline RURALNESS & -0.207 & -0.362 & 0.016 & -0.262 & 0.215 & -0.094 & 1.000 & & & & & \\
\hline YOGYA & 0.123 & 0.265 & 0.028 & 0.004 & -0.156 & -0.035 & -0.544 & 1.000 & & & & \\
\hline SLEMAN & 0.021 & 0.158 & 0.068 & 0.121 & -0.039 & 0.147 & -0.281 & -0.249 & 1.000 & & & \\
\hline BANTUL & 0.106 & -0.135 & -0.081 & 0.241 & -0.030 & 0.007 & -0.207 & -0.249 & -0.251 & 1.000 & & \\
\hline KULONPROGO & -0.110 & -0.257 & 0.011 & -0.113 & 0.142 & -0.115 & 0.442 & -0.249 & -0.251 & -0.251 & 1.000 & \\
\hline GUNUNGKIDUL & -0.139 & -0.031 & -0.025 & -0.253 & 0.083 & -0.004 & 0.588 & -0.249 & -0.251 & -0.251 & -0.251 & 1.000 \\
\hline
\end{tabular}

This table presents the correlation matrix of variables. READINESS is an index to measure the perceived readiness in the implementation of digital financial services. INFRA is an index to measure the perceived quality of supporting infrastructure. GENDER is a dummy variable, taking a value of 1 for male and 0 for female. EDU is the level of education. AGE is the age of respondent. INCOME is the level of income. RURAL is the level of ruralness. 


\section{DISCUSSION}

Financial technology has been an interesting issue over the last few years along with the development of information and communication technology which lead to a number of technological-based financial services. Many features of financial technology have been implemented including electronic money, mobile payment, crowd funding, peer-to-peer lending and others. The proponents of financial innovation argue that the faster the adoption of technology in the financial intermediation activities, the higher the financial inclusion would be. However, it should also be noted that there is a significant disparity in the level of readiness in the implementation of digital financial services across individuals, regions and countries. It implies that the readiness level at the individual and regional levels should be regarded in the extent to which digital financial services will be implemented. Less readiness level of society would imply that the implementation of digital financial services could not be effective.

Table 3. Regression Results

\begin{tabular}{lrrr}
\hline & Readiness & Readiness & Readiness \\
\hline Infrastructure & $0.059^{* * *}$ & $0.061^{* * *}$ & $0.0675^{* * *}$ \\
Gender & $(5.360)$ & $(5.395)$ & $(5.991)$ \\
& $0.177^{*}$ & $0.186^{*}$ & $0.189^{*}$ \\
Education & $(1.714)$ & $(1,800)$ & $(1.843)$ \\
& $0.270^{* * *}$ & $0.267^{* * *}$ & $\left(5.255^{* * *}\right.$ \\
Age & $(5.256)$ & $-0,027^{* * *}$ & $(4.960)$ \\
Income & $-0.027^{* * *}$ & $(-6.036)$ & $-0.027^{* * *}$ \\
& $(-6.044)$ & $0.152^{* * *}$ & $(-6.028)$ \\
Ruralness & $0.153^{* * *}$ & $(3.8090)$ & $0.151^{* * *}$ \\
& $(3.847)$ & & $(3.811)$ \\
Number of Bank & 0.218 & & \\
Population per bank & $(0.860)$ & -0.008 & $(-1.162)$ \\
Yogya & & & $0.289^{* * *}$ \\
Sleman & & & $(2.862)$ \\
Bantul & & 0.194 & 0.242 \\
& 0.357 & $(1.152)$ & $(1.435)$ \\
Gunungkidul & $(1.392)$ & -0.129 & -0.229 \\
Constant & -0.055 & $(-0.761)$ & $(-1.383)$ \\
& $(-0.256)$ & $0.307^{*}$ & 0.175 \\
Method & $0.415^{* *}$ & $(1.904)$ & $(1.054)$ \\
Rumber of Observations & $(1.987)$ & -0.239 & $-0.426^{* *}$ \\
Adj-R squared & -0.254 & $(-1.487)$ & $(-2.439)$ \\
\hline
\end{tabular}

The values in parentheses are t-statistics. ${ }^{*}, * *$ and $* * *$ indicate significance at the $10 \%, 5 \%$, and $1 \%$ levels, respectively. 


\section{How Ready are People for Cashless Society? \\ Irwan Trinugroho, Hunik Sri Runing Sawitri, Muh Juan Suam Toro, Siti Khoiriyah, \& Arief Budi Santoso}

By studying individual and regional level, according to our findings, there are at least three important factors determining the perceived readiness of the implementation of digital financial services. The first one is infrastructures, more particular information and communication technology infrastructure, which is measured by the perception survey on the quality of infrastructures. Second, some demographic factors which are related to the level of financial literacy such as education and age matter to explain the difference in perceived readiness to use digital financial services. The last one is regional characteristics. These findings are consistent with the work of Astuti \& Trinugroho (2016) which finds that the higher the levels of financial literacy of people in the regions, the more the willingness to engage with formal financial institutions. Also, it is in line with the study of Trinugroho et al. (2015) which reveal that banking development at the regional level in Indonesia is strongly influenced by the characteristics of regions particularly the quality of local governance and the socio-economic condition.

The other important note for the implementation of digital financial service as a part of financial technology is related to the risk. As mentioned by Beck et al. (2016), digital financial services as a part of financial innovation, on the one hand, could lead to faster bank growth. On the other hand, however, it could also create bank fragility especially in the crisis period. Therefore, the quality of regulation should be regarded to minimize the incentive to moral hazard and excessive risk taking behaviours.

\section{CONCLUSION AND SUGGESTION}

\section{Conclusion}

We study the determinants of readiness in the implementation of digital financial services which is the basis of cashless society by studying 993 respondents in a province in Indonesia. Ac- cording to our survey, $50 \%$ of respondents agree for the important of cashless model in the financial transactions. Our results support the contending that perceived readiness is positively correlated with perceived quality of supporting infrastructure. Demographic factors, especially age and education, are also found to explain the difference in readiness to use digital financial services. Socioeconomic condition is also found to have an impact of the eagerness to adopt the new system. No evidence is found for the difference inclination between rural and urban people.

\section{Suggestion}

However, this study is only limited to a province in Indonesia. We strongly recommend future studies to extend our work by studying across provinces in Indonesia. It would reveal a more comprehensive view on the readiness to implement the digital financial services. Moreover, by doing cross regions research, it could enable the study to look at the role of local institutional development in explaining the difference in readiness level as previously documented by Trinugroho et al. (2015) and Trinugroho and Wiwoho (2016). In the future study, it would also be more beneficial to employ some objective measures for the ICT infrastructure for the digital financial services rather than using the perception survey. Moreover, the readiness level should also be measured using objectives proxy such as the ratio people who use digital financial services over population.

Practically speaking, there is also some noteworthy policy implications resulted from this study. First, to accelerate the level of financial inclusion, the implementation of digital financial services in Indonesia should be continued especially in the remote areas where the availability of formal financial institutions is limited. Second, improving the quality of supporting facilities, especially the ICT infrastructure, is strongly needed 
for the implementation of cashless system particularly the telecommunication and information technology. Third, as some demographic aspects are important to explain the perceived readiness, it should be taken into account for policy consideration. More particular, bolstering the level of financial literacy, particularly for relatively less educated people should be done to improve the readiness level of society.

\section{REFERENCES}

Astuti, P.H., \& Trinugroho, I. 2016. Financial Literacy and Engagement in Banking. Journal of Economics and Economic Education Research, 17(1): 1-6.

Beck, T., Demirguc-Kunt., A., \& Honahan, P. 2009. Access to Financial Services: Measurement, Impact, and Policies. The World Bank Research Observer Advance Access, Oxford University Press.

Beck, T., Chen, T., Lin, C., \& Song, F.M. 2016. Financial Innovation: The Bright and The Dark Sides. Journal of Banking and Finance, 72: 28-51.

Dahlberg, T., Guo, J., \& Ondrus, J. 2015. A Critical Review of Mobile Payment Research. Electronic Commerce Research and Applications 14(5): 265-284.

Diniz, E., Birochi, R., \& Pozzebon, M. 2012. Triggers and Barriers to Financial Inclusion: The Use of ICTbased Branchless Banking in an Amazon County. Electronic Commerce Research and Applications, 11(5): 484-494.

Gupte, R., Venkataramani, B., \& Gupta, D. 2012. Computation of financial inclusion index for India. Procedia Social and Behavioral Sciences 37, 133-149.

Gwalani, H. \& Parkhi, S. 2014. Financial inclusion - Building a success model in the Indian context. Procedia Social and Behavioral Sciences, 133: 372-378.
Hernando, J.R. 2016. Crowdfunding: The Collaborative Economy for Channeling Institutional and Household Savings. Research in International Business and Finance, 38: 326-337.

Karsidi, R., Trinugroho, I., Nugroho L.I., \& Prabowo, A. 2015. Why Households Borrow from Informal Predatory Lenders: Evidence from Indonesia. Journal of Economics and Economic Education Research, $16(2), 173-182$

Milne, A. \& Parboteeah, P. 2016. The Business Models and Economics of Peer-to-Peer Lending. Working Paper, 1-39.

Parker, S.C. 2014. Crowdfunding, Cascades and Informed Investors. Economics Letters, 125: 432-435.

Pradhan, R. P., Arvin, M.B., \& Norman, N. R. 2015. The Dynamics of Information and Communications Technologies Infrastructure, Economic Growth, and Financial Development: Evidence from Asian Countries. Technology in Society 42, 135-149.

Santoso, A.B., Trinugroho, I., Nugroho, L.I, Saputro, N., \& Purnama, M.Y.I. 2016. Determinants of Financial Literacy and Financial Inclusion Disparity within a Region: Evidence from Indonesia. Advanced Science Letters, 22: 1622-1624.

Trinugroho, I., Agusman A., Ariefianto, M..D., Darsono, D., \& Tarazi, A. 2015. Determinants of Cross Regional Disparity in Financial Deepening: Evidence from Indonesian Provinces. Economics Bulletin, 35(2): 896-910.

Trinugroho, I. \& Wiwoho, J. 2016. Local Institutional Development and Cost of Financial Intermediation: Evidence from Indonesia. International Journal of Business 21(4), 319-327. 